\title{
DOMNIEMANE DATOWANIE NIEDATOWANYCH UTWORÓW KAROLA WOJTYŁY: DZIEEA LITERACKIE I TEATRALNE, JUVENILIA (1938-1946)
}

Karol Wojtyła pozostawił po sobie wiele niedatowanych utworów. Ustalenie czasu ich powstania wymaga niekiedy detektywistycznego wręcz zacięcia. Nawet jeśli nie poznamy już dziennej daty napisania danego utworu, to jednak zawarte w każdym z nich informacje mogą posłużyć jako drogowskazy w celu choćby przybliżenia kontekstów, w których te teksty powstawały.

Najstarszym zachowanym tekstem spisanym ręką 17-letniego Karola Wojtyły jest Obraz sceniczny pt. , Chrystus - Król” na podstawie Apokalipsy św. Jana, zachowany w Archiwum Kurii Metropolitalnej w Krakowie. Rękopis stanowi jedyną, jak dotąd, odnalezioną adaptację sceniczną do jednej z wielu sztuk, w których wystąpił młody Karol Wojtyła w Wadowicach. Tekst jest spisany piórem na kartce papieru, mocno pożółkłego, a dopiski między wersami naniesione ołówkiem dotyczą wskazówek scenicznych dla roli Jana, którą to interpretował Karol Wojtyła. Z relacji świadków wynika, że sztuka była wystawiona z okazji święta Chrystusa Króla na scenie Domu Katolickiego w Wadowicach w reżyserii ks. dr. Edwarda Zachera i Karola Wojtyły (Gruszczyńska 19; Wadowice 63). Według klasztornej kroniki „wielka akademia ku czci Chrystusa Króla oraz przepiękne misterium na tle wizji apokaliptycznej św. Jana Ewangelisty" miały miejsce 25 października 1937 roku (Wadowice 63), jednak wskazane święto sugerowałoby na przesunięcie daty na 25 listopada tegoż roku. Oba źródła są zgodne co do sukcesu, tak pod względem frekwencji, jak i mistrzowskiej interpretacji aktorów oraz chóru gregoriańskiego. Sam autor oprawy muzycznej, prof. Józef Titz, precyzował, że muzykę dla zespołu smyczkowego

Dr Marta Burghardt - Instytut Dialogu Międzykulturowego im. Jana Pawła II w Krakowie; adres do korespondencji: ul. Totus Tuus 30,30-610 Kraków; e-mail: instytut@idmjp.2.pl 
skomponował na motywach zaczerpniętych z kantyku gregoriańskiego, że zaangażował chóry gimnazjalne męski i żeński, że dziewczęta wystąpiły w roli aniołów, a „na tle anielskich chórów Lolek [Karol Wojtyła] recytował tekst ewangeliczny, występując jako święty Jan. [...] Mieliśmy kolosalne powodzenie. Utwór brzmiał potężnie dzięki młodym głosom i dobrej akustyce" (cyt. za: Bieniasz 65).

Najwcześniejszym z zachowanych utworów literackich autorstwa Karola Wojtyły jest wiersz wpisany do pamiętnika Danuty Pukłówny z 25 maja 1938 roku, zaczynający się od słów: „Są takie święte, jasne dni”. Wiersz jest sygnowany przez Autora inicjałami K.W., nie stanowi części tomiku pt. Psałterz Dawidów (Księga stowiańska), ani też zaginionego tomiku Ballady beskidzkie. Został skomponowany na potrzebę chwili, w czasie przyjęcia pomaturalnego, które odbywało się w domu państwa Pukłów w Wadowicach ${ }^{1}$. Świętująca absolwentka gimnazjum żeńskiego zaprosiła liczne grono przyjaciół, młodzież bawiła się przy muzyce granej na fortepianie. Wśród zaproszonych znalazł się Karol Wojtyła i kiedy go Danuta poprosiła o wpis do pamiętnika, uczynił to chętnie i napisał jej ów ułożony przez siebie wiersz (Gruszczyńska 34-35), tym cenniejszy, że jedyny ocalały z okresu wadowickiego. Pozostałe utwory powstały już w Krakowie, z dala od ukochanych Wadowic, niektóre nawet z nutą tęsknoty za górami Beskidów.

Najwcześniejszym spośród utworów wchodzących w skład Psałterza Dawidów

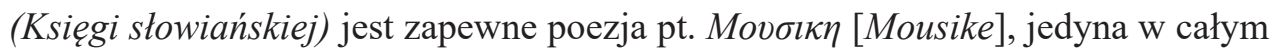
tomiku opatrzona datą dzienną: 31 grudnia 1938 roku, a dokładnie dopiskiem uczynionym ręką Autora: „natchnięte i spisane 31 XII 1938”. Wchodzące w skład tegoż tomiku Sonety I-XVII Autor opatrzył adnotacjami dotyczącymi czasu ich powstania: „wiosną 1939” i ,skończyłem na Święty Jan 1939”. Z kolei komentarz Do sonetów! zawiera dopisek autorski „roku wojny”, a w samym komentarzu Autor pisze: „--Sonety: Pieśni wiosny, wiosny roku tragicznego. Pieśni ufne we wigilią strasznych dni” (Wojtyła, Dzieła literackie 1: 61). Z tego wynika, że tekst komentarza jest przynajmniej o kilka miesięcy późniejszy od cyklu Sonetów. Zapis „,roku wojny” można interpretować dwojako: albo komentarz Do sonetów! powstał w okresie od 1 września do 31 grudnia 1939, albo od 1 września 1939 do 1 września 1940 roku. Pozostałe teksty nie zostały opatrzone przez Autora datami. Wiersz - inwokację bez tytułu, zaczynający się od słów: „Nad Twoją białą mogiłą”, Karol Wojtyła poświęcił matce nieżyjącej od 13 kwietnia 1929 roku. Wiersz powstał zatem w 10 rocznicę jej śmierci, wiosną 1939 roku. W podobnym czasie powstały utwory: Biesiada (- Poezja -),

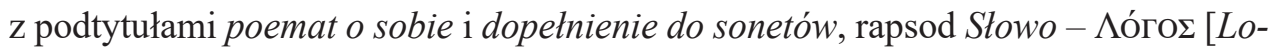

\footnotetext{
${ }^{1}$ Pamiętnik aktualnie przechowywany jest w zbiorach Muzeum Dom Rodzinny Ojca Świętego Jana Pawła II w Wadowicach. Utwór po raz pierwszy był podany do druku według tegoż rękopisu w publikacji: D. Gruszczyńska, W Wadowicach wszystko się zaczęło...
} 
gos], które razem z Mousike stanowią Symphonie - Scalenia oraz hymn Magnificat i Przypisy do „Psalterza - Księgi Stowiańskiej” (1: 407-408).

Zachowana w rękopisie Ballada wawelskich arkad powstała najprawdopodobniej przed wybuchem wojny, ale w mocnym poczuciu nadchodzącego niebezpieczeństwa: „gromy coraz bliżej”, „za oknem nawała krucza”. W utworze ponadto jest mowa o ciszy przed burzą i o lipcowym upale. Obok słów zbliżonych do modlitwy: „Ojcze! nie dopuść, / aby zdeptały tabuny, / by na kopytach rozniosły / Batuchanowe hordy / ludzki ród!”, przeplatanych obecnością św. Szczepana męczennika „żadną nie osłoniętego tarczą", wywiedzionego poza mury na kamieniowanie, jest i nawiązanie do przejścia Izraelitów przez Morze Czerwone oraz do obłoku, w którym Bóg przyszedł i przemówił do Mojżesza. Z jednej strony jest poczucie bezsilności: „Trawy gniecione przez wiatr modlitwy mruczą", a z drugiej - jest i przywołanie pieśni sławy od Mieszka i od Chrobrego, przypomnienie o znaczących zrywach patriotycznych, np. nawiązanie do powstania listopadowego. A Bóg jak Fryderyk odziany w surdut, uderza w klawisze: białe, pod którymi kryją się: miłość, czas pokoju, ukwiecone łąki, śpiew ptaków, kwitnący jaśmin, pasące się owce na halach, delikatny powiew wiatru, rozgwieżdżone niebo... oraz w czarne klawisze w deszczu moknące, symbolizujące: miecze, igliwie bagnetów, bojowe surmy, atak piechoty, wyrwane ramiona żywe, ciała na pobojowiskach, krwawiącą ziemię, śmierć w odmętach, broń na mogiłach, trzaskające konary drzew, płonące krzyże (1: 97-107).

Wiele wspólnego z Ballada wawelskich arkad ma poemat zatytułowany Mousike [2] (dla odróżnienia od utworu z 1938 roku o tym samym tytule, umownie jest oznaczany jako Mousike [2]). Można przypuszczać, że stanowi wręcz późniejszą i poszerzoną wersję Ballady. Utwór powstał najprawdopodobniej jesienią 1939 roku, nie zachował się w formie rękopiśmiennej, lecz tylko w formie maszynopisu. Nie stanowi części żadnego ze znanych nam zbiorków poetyckich. Mousike [2] liczy ponad 400 wersów, z czego jedna trzecia została zaczerpnięta wprost z rękopisu Ballady wawelskich arkad. Bolesław Taborski zainteresowany wydaniem tegoż poematu poprosił Ojca Świętego o zgodę na jego publikację w 1986 roku, ale w odpowiedzi otrzymał zaskakującą informację: „Niestety. Nie przypominam sobie, abym napisał taki utwór. Bardzo żałuję. JP” (1: 527).

Pieśn poranna to utwór napisany najpewniej jesienią 1939 roku, zachowany w dwóch kopiach maszynopisu Renesansowego psałterza (Ksiegi słowiańskiej). Zastanawia fakt, dlaczego w wydaniach opracowanych przez Marka Skwarnickiego zawsze ten utwór bezpośrednio poprzedzał Sonety. Nie jest wykluczone, że ów utwór stanowił część większej całości. Z roku 1939, ale już z okresu okupacyjnego pochodził dramat pod tytułem Dawid (tekst dotychczas nieodnaleziony). Wojtyła pisał o nim w liście do Kotlarczyka z 28 grudnia 1939 roku: „Napisałem dramat, ściślej poemat dramatyczny. Nazywa się Dawid, chodzi w stroju biblijnym i w piastowskiej 
płótniance i w karmazynowej delii. Wiele rzeczy, wiele spraw duszy swojej w nim objawiłem. ... Dawid jest z prozy, z wiersza, z białego, z rymowanego - serdeczny" (1: 353). To właśnie w Pieśni porannej Dawida - Pasterza mamy Piastowego syna w płótniance i namaszczonego króla Izraela: „Panie, jam Dawid, syn Izai, / Piastowy jestem syn. / Ty mi na sercu znak wypalisz - / zasłucham się w Twój rym” (1: 108).

Poezją datowaną na jesień 1939 roku jest ... a gdy przyszedt Dawid do ziemi macierzy swej. Także ten utwór, zachowany w dwóch kopiach maszynopisu Renesansowego psałterza (Księgi słowiańskiej), we wszystkich opracowaniach Marka Skwarnickiego miał swoje stałe miejsce: był zawsze zamieszczany po Sonecie XVII. Kontynuując zapoczątkowany tok myślenia, także ten utwór śmiało można by wpisać w część zaginionego Dawida, tym bardziej że zgadzałaby się data jego powstania, przypadająca na początek wojny: „O ziemio, moja ziemio! Tyś mi dziesięcinę / obrodziła najpierwszą pieśnią i młodością, / twoim chlebem się sycił, napawałem winem, / aż oto mi tęsknoty wiatr jesienny rozciął, / jakby jednym zamachem, jednym ciosem miecza, poobalał posągi, widzenia pokruszył - / i kazał mi się z pieśnią, z tęsknotą mą sprzeczać / i potargał cięciwę piętej pieśnią kuszy" (1: 109). Mocniej jeszcze przemawiają kolejne wersy: „I jam się też rozszumiał - buk między bukami, / tako mi święte stało pasterskie śpiewanie, / żem zamarzył - syn Piastów - izraelski Dawid, by mi na czoło Pańskie zeszło pomazanie...” (1: 110).

Przytoczone fragmenty być może pochodzące z zaginionego dramatu pt. Dawid nie odbiegają daleko pod względem stylistycznym od dwóch zachowanych dramatów: Hioba - napisanego w Wielkim Poście 1940 roku i Jeremiasza, który mógł powstać między Wielkanocą a latem 1940 roku. Na temat Hioba Autor wynotował w liście do Mieczysława Kotlarczyka:

Ja sam napisałem dramat nowy. Grecki formą, chrześcijański duchem, odwieczny treścią [...] Dramat o cierpieniu: Hiob. Wcale się to niektórym ludziom podoba. Wynikło to w pewnej mierze z tego, że zagłębiłem się w Stary Testament. Przeczytałem Psalmy Dawida, Księgę Hioba, Księgi Mądrości, teraz Proroków. Poza tym z ważniejszych: Słowacki i nowa sztuka (genialna rzecz) ${ }^{2}$, a obecnie Wykłady z literatury słowiańskiej Mickiewicza. (1: 355-356)

W kolejnym, ale już niedatowanym liście ${ }^{3}$ znów do Mieczysława Kotlarczyka streszcza oba dramaty, a na temat powstania drugiego z nich pisze: „Następne osiągnięcie to dramat, który się na razie nazywa Jeremiasz, ale będzie się, zdaje się,

${ }^{2}$ Za genialną rzecz Autor uznał publikację Ignacego Matuszewskiego pt. Słowacki i nowa sztuka (modernizm). Twórczość Stowackiego w świetle pogląów estetyki nowoczesnej. Studium krytyczno-porównawcze, Gebethner i S-ka, 1904.

${ }^{3} \mathrm{Na}$ podstawie zawartych w liście informacji, które dotyczą obwieszczenia Generalnego Gubernatora o obowiązku pracy ludności polskiej, list można datować na dzień 11 lipca 1940 roku. 
nazywał Zakon. Powstał błyskawicznie, jako objawienie podczas czytania Proroctw Jeremiasza. [...] Ów Zakon zarysowuje mi się w tej chwili już dość wyraźnie jako jedna część Tetralogii" $(1: 358,359)$.

Te trzy pierwsze dramaty Karola Wojtyły, powstałe w okresie wojennym, w czasie przerwanych studiów polonistycznych ${ }^{4}$, na silnej podbudowie biblijnej i pod wpływem dzieł Słowackiego i Mickiewicza, Stanisław Dziedzic określa jako tzw. dramaty polonistyczne: „Z okresu pierwszych wojennych miesięcy pochodzi nie odnaleziony dotąd dramat Dawid oraz następne dwa dramaty - Hiob i Jeremiasz, zwane, dla odróżnienia od późniejszych, osadzonych w formule rapsodycznej, właśnie dramatami polonistycznymi. [...] W okresie wojennym Wojtyła [...] bardzo doskonali swoje artystyczne i intelektualne ego” („Krakowski świat młodego Karola Wojtyły"). Potwierdzeniem tej tezy są słowa Jana Pawła II wypowiedziane podczas sympozjum slawistów w Castel Gandolfo w 1996 roku:

Tak więc od 6 listopada przestałem przemierzać moją codzienną drogę z Dębnik na ul. Gołębią. Pracowałem natomiast w domu przy ul. Tynieckiej 10, poświęcając czas osobistym studiom i twórczości. Młodzieńcze utwory poetyckie pochodzą z tego właśnie okresu. Trwało to przez jeden rok, do 1 września 1940 roku, gdy zacząłem pracować w kamieniołomie należącym do fabryki Solvay. (Cyt. za: Dalgiewicz 24)

Na okres wojny i okupacji przypadają także utwory Mściciele, Proletariat, Przełom i Dialog w ciemności. Żaden z nich nigdy nie doczekał się autoryzacji Ojca Świętego, są określane jako „utwory niepotwierdzonego autorstwa”. O ile trzy pierwsze przetrwały w formie rękopiśmiennej, a Proletariat nawet w czterech odmiennych wersjach, z czego można by wnosić, że te wiersze nie były obojętne Autorowi w chwili ich pisania, to Dialog w ciemności znamy tylko z maszynopisu, załączonego do listu Jerzego Turowicza do Jana Pawła II z 16 czerwca 1979 roku (Wojtyła, Dzieła literackie 1: 525). Najtrudniej odnieść się właśnie do tego ostatniego utworu; nie wiadomo, czy zachował się on w rękopisie, a maszynopis jest zbyt „nowy”, aby z niego móc cokolwiek wnieść do historii tekstu. Mieli z nim „problem” redaktorzy pierwszego wydania Poezji i dramatów, o czym może świadczyć fragment ich listu wysłany do Autora: „Dialog w ciemności to wiersz bardzo piękny i dojrzały i chętnie włączylibyśmy go do tomu, ale nie możemy tego zrobić bez wyrażenia placet Ojca. Dlatego ten jeden wiersz dołączamy do teczki maszynopisów, prosząc o wyraźną

\footnotetext{
${ }^{4}$ W Krakowie na studiach polonistycznych na Uniwersytecie Jagiellońskim młody Wojtyła uczęszczał na zajęcia: „Teatr i dramat w Polsce od połowy XVIII wieku”, prowadzone przez prof. Stanisława Pigonia, „Analiza teorii dramatu” oraz „Dramat w dobie naturalizmu i Młodej Polski” prowadzone przez prof. Stefana Kołaczkowskiego, „Interpretacja dramatyki (Wyspiański)” w pierwszym trymestrze, „Interpretacja dramatyki (Rostworowski)” w drugim trymestrze, „Interpretacja najnowszej dramatyki” w trzecim trymestrze, a wszystkie je prowadził lektor dr Władysław Dobrowolski.
} 
decyzję, co do ewentualnego druku" (1: 30). Nie zamieszczenie tego wiersza w tomie ewidentnie świadczy o nie wyrażeniu zgody przez Jana Pawła II na jego publikację. Ponadto tematycznie wiersz ten zdaje się odbiegać od innych dzieł literackich Karola Wojtyły. Można się dopatrywać jedynie kilku leksykalnych podobieństw z Mousike [2] i z Ballada wawelskich arkad, ale tak jak zauważają redaktorzy w 1979 roku, jest to wiersz dojrzały, można przypuszczać zatem, że i późniejszy.

Utwór pt. Mściciele został napisany najprawdopodobniej w połowie 1940 roku w Krakowie, zachował się w rękopiśmiennym brulionie. Nie stanowi części żadnego ze znanych nam zbiorków poetyckich Autora. Ze względu na bezpośredni zwrot do Francji: „Któż Ciebie pomści Francjo - galicka córko sprzedajna”, można by się domyślać, że wiersz został napisany po jej kapitulacji, czyli po 22 czerwca 1940 roku, gdyż - jak wspominali świadkowie tamtych dni z otoczenia Wojtyły - był to dla nich jeden z najboleśniejszych momentów w czasie całej wojny i okupacji (1: 529). Wraz z kapitulacją Francji umarła nadzieja na szybkie zakończenie wojny.

Podobnie Proletariat nie stanowi części żadnego ze znanych nam zbiorków poetyckich Karola Wojtyły, zachował się w czterech rękopiśmiennych brulionach. Utwór został napisany najprawdopodobniej jesienią 1940 roku, w każdym razie nie jest to tekst odległy w czasie od wiersza pt. Mściciele, skoro na jego odwrocie została spisana jedna z wersji brulionowych właśnie Proletariatu. Warto przypomnieć, że we wrześniu 1940 roku Wojtyła podjął pracę w Solvayu; przez pierwszy rok był zatrudniony w kamieniołomie na Zakrzówku. Został przydzielony do pracy na torach, czyli naciągał tory, wyrównywał teren pod nie, chodził z łopatą, podsypywał pod progi i pod tory, czasami spinał z kolegami wózki kolejki. Wówczas prawdopodobnie napisał ten wiersz o tematyce społecznej, o ludziach pracy, bo sam z nimi obcował, poznał trud fizycznego wysiłku, czasami ponad ludzkie siły, otarł się o ubóstwo i niedolę współpracowników, był świadkiem ich codziennego bohaterstwa i chętnie je podzielał ${ }^{5}$. Proletariat nawiązuje także do wojny domowej w Hiszpanii (1936-1939).

\footnotetext{
${ }^{5}$ Od lata 1941 do sierpnia 1944 Karol Wojtyła przeważnie pracował w systemie trzyzmianowym, już nie w kamieniołomie, ale w oczyszczalni wody. Na początku zmiany przynosił około czterech wiader wapna, w zależności od alkaiczności wody, wapno wsypywał do zbiornika zalewał wodą, ten roztwór spuszczał do leja. Następnie szedł po dwa wiadra sody lub kaustyku (ług kaustyczny był potrzebny do zmiękczania wody). W zależności od polecenia z laboratorium w osobnym zbiorniku rozpuszczał kaustyk lub sodę, a zawartość tego zbiornika wystarczała na około 4 godziny. Jako robotnik był biedny, stołował się w kuchni fabrycznej, gdzie przysługiwało mu pół litra zupy i 10 dag chleba. Panie z kuchni często zostawiały dla niego większą kromkę chleba, bo wiedziały, że tyle je „co zje na fabryce” i nazywały go „pobożnym chłopakiem”, ponieważ często wymykał się z pracy do kościoła np. na nabożeństwa majowe, czy na różaniec, wiedziały że jest kształcony i pisał wówczas coś o św. Teresie. Był zawsze grzeczny, pogodny i uprzejmy, potrafił każdego pocieszyć i podnieść na duchu. O szczegółach tej jego pracy wiemy dzięki relacjom spisanym z taśmy magnetofonowej
} 
Przełom najprawdopodobniej został napisany pod koniec 1940 lub w 1941 roku. Zachował się w rękopiśmiennym brulionie i również nie stanowi części żadnego ze znanych nam zbiorków poetyckich Wojtyły. Jan Paweł II „przełomem” w swoim życiu nazwał spotkanie z Janem Tyranowskim (Frossard 19). Warto przypomnieć, że swojego świeckiego ojca duchownego, Tyranowskiego, poznał w lutym 1940 roku, pod jego wpływem zapisał się do Żywego Różańca oraz do Kółka Biblijnego w parafii dębnickiej. Często przechadzali się bulwarami nad Wisłą, wzdłuż ul. Tynieckiej. Świadkowie tamtych dni pisali, że Wojtyła był wręcz ,pupilem Mistrza” (cyt. za: Kalendarium 71). Szeptano o rozmowach dwóch charyzmatyków. Od Wojtyły z kolei wiemy, że prowadzili dialogi na temat św. Jana od Krzyża, św. Teresy od Jezusa, na temat istoty cnót boskich, sposobów rozmyślania, czy tajemnicy darów Ducha Świętego. Z korespondencji Jana Tyranowskiego wynika, że miał wiele do zaoferowania młodzieży, dla której wykładał psychologię, logikę, metafizykę, dogmatykę, liturgię, historię Kościoła, teologię ascetyczną, teologię mistyczną oraz prowadził wykłady o życiu wewnętrznym, ale przede wszystkim wprowadzał w tajniki nadprzyrodzonej transcendencji (Perła ewangeliczna 70). Przełomem w życiu młodego Wojtyły, jak utrzymywali np. Danuta Michałowska czy Juliusz Kydryński, było odejście jego ojca, który zmarł 18 lutego 1941 w wieku sześćdziesięciu dwóch lat. Karol miał zaledwie 21 lat i już nie miał nikogo z najbliższej rodziny. Codziennie chodził na cmentarz i na mszę św. do kościoła, dużo się modlił u siebie w pokoju, leżał krzyżem na podłodze. Przełomem mogło być także zbliżenie się latem 1942 roku do karmelitów bosych. Karol Wojtyła wziął udział w obchodach czterechsetnej rocznicy urodzin św. Jana od Krzyża ${ }^{6}$. Wtedy to miał po raz pierwszy wyrazić swą wolę wstąpienia do karmelitańskiego zakonu. Jednak był to okres wojny, a władze okupacyjne nie zezwalały na przyjmowanie kandydatów do nowicjatu.

Nie można też wykluczyć prawdopodobieństwa, że wyżej wymienione wiersze powstały w wyniku rozmów Karola Wojtyły z Tadeuszem Kwiatkowskim, Juliuszem Kydryńskim, Wojciechem Żukrowskim i Jerzym Boberem na tematy poezji i szerzej

\footnotetext{
i umieszczonym w dokumencie zatytułowanym „Gniazdo, z którego wyszedłem”, którego oprawiony maszynopis został ofiarowany księdzu arcybiskupowi Karolowi Wojtyle 5 maja 1966 roku. Informacje zebrała i opracowała Karolina Biedrzycka (Gniazdo, z którego wyszedtem).

${ }^{6}$ Jubileuszowym obchodom towarzyszyła publikacja: Pamiatka 400-lecia urodzin św. Jana od Krzyża 1542-1942. Krótki życiorys. List pasterski Generała Zakonu OO. Karmelitów Bosych, wydana nakładem Ojców Karmelitów Bosych z Rakowickiej 18 w Krakowie w listopadzie 1942 roku. Na uwagę zasługuje fakt, że tę małą książeczkę nabył 22-letni Karol Wojtyła, robotnik fizyczny z fabryki „Solvay”, towarzyszyła mu w czasie okupacji, nie wiadomo czy miała wpływ na budzące się w nim powołanie duchowne, ale na pewno wpłynęła na późniejszy wybór tematu pracy naukowej, towarzyszyła przy rozlicznych przeprowadzkach i do dzisiaj stanowi część księgozbioru biblioteki podręcznej kardynała Karola Wojtyły w Kurii Metropolitalnej w Krakowie, biblioteki, która nie pojechała do Watykanu za swym właścicielem.
} 
- na tematy literatury oraz jej nowych trendów. Dorobek każdego z nich w okresie okupacji musiał być imponujący, skoro nie zawahali się ryzykownego wydawania konspiracyjnego pisma. Warto przypomnieć, że siedem numerów Miesięcznika Literackiego wydanych od listopada 1942 do czerwca 1943 roku redagowali Tadeusz Kwiatkowski i Wojciech Żukrowski, a Juliusz Kydryński zadebiutował na jego łamach jako prozaik?

Ze względu na skoncentrowanie się na tematyce religijnej właśnie w Przełomie można się dopatrywać wprowadzenia do utworu medytacyjnego [Ciagle jestem na tym samym brzegu] oraz do wersji brulionowej [Przyjaciela naszego Boga]. Każda strona tych dwóch ostatnich tekstów (a potem już każdego następnego dzieła Wojtyły zachowanego w rękopisach) rozpoczyna się od incipitów AMDG [Ad Maiorem Dei Gloriam], czyli ,na większą chwałę Bożą” w lewym rogu, a w prawym rogu J+M [Jezus i Maryja], a między nimi wybrane wersety aktów strzelistych, fragmenty traktatu Ludwika Marii Grignon de Montfort lub wezwania do świętych, tu także św. Teresy i św. Jana od Krzyża, jest między innymi także wezwanie, które w zapiskach Jana Tyranowskiego zamyka ofiarowanie się, czyli: „Bóg mój i wszystko”. Inicjały AMDG widnieją także na zachowanych książkach należących niegdyś do podręcznej biblioteki Jana Tyranowskiego ${ }^{8}$.

Wiele trudności przysparza także datowanie utworu medytacyjnego zaczynającego się od słów: „Ciągle jestem na tym samym brzegu”, zachowanego w formie rękopisu i zapisanego obustronnie ołówkiem na bardzo pożółkłych pięciu kartkach, podobnych do tych, na jakich zostały zapisane wiersze Mściciele i Proletariat i podobnie jak ten ostatni, także ołówkiem. Sądząc po sygnaturze nadanej przez archiwistę tekst ten najpewniej był przechowywany w Kurii Metropolitalnej w Krakowie, od kiedy jego Autor zamieszkał przy ul. Franciszkańskiej 3. Prawdopodobnie nie został opublikowany w wydaniu z 1979 roku Poezji i dramatów, gdyż nie został zaliczony ani do poezji, ani do dramatów. Nie wspominają o nim ani Turowicz, ani Skwarnicki w korespondencji, jaką prowadzili z Watykanem w celu ustalenia zawartości

\footnotetext{
${ }^{7}$ Encyklopedia Krakowa podaje: „«Miesięcznik Literacki», czasopismo konspiracyjne, wyd. XI 1942-VI 1943 (7 zeszytów) przez chrześc.-demokr. organizację Unia, pod redakcją T. Kwiatkowskiego i W. Żukrowskiego; drukowane w mieszkaniu T. Kwiatkowskiego, w pracach techn. uczestniczył rzeźbiarz T. Ostaszewski; utwory poet. i beletrystyczne zamieszczali m.in. K.K. Baczyński, T. Kwiatkowski, J. Kydryński, M. Morstin-Górska, J.B. Ożóg, J. Twardowski, W. Żukrowski, artykuły i eseje — T. Kudliński, J. Spytkowski, S. Szuman, J. Turowicz, K. Wyka; „M.L.”. Z kolei pod hasłem „Okres 1939-45" możemy dodatkowo przeczytać, że w 1943 roku ukazał się w nim artykuł K. Wyki List do Jana Bugaja, poświęcony twórczości K.K. Baczyńskiego. Nie jest wykluczone, że pod wpływem publikacji wymienionych autorów mógł powstać wiersz Dialog w ciemności oraz inne utwory z okresu wojny i okupacji.

${ }^{8}$ Są to m.in.: Ewangelie i Dzieje apostolskie w przekładzie J. Wujka, Mszał rzymski oraz „Pełnia umiejętności świętych. Zasadnicze wskazówki dla postępujących” Aleksandra Żychlińskiego.
} 
tomu. Czytając między wersami możemy się domyślać, że w okresie pisania tego utworu Karol Wojtyła uczył się języka francuskiego ${ }^{9}$, a może właściwie znał go już na tyle, aby czytać literaturę francuską w oryginale: „Na stole pod lichtarzem leżała otwarta francuska literatura. Pochyleni nad nią uczyli się dziś w ostatnim pokoju” (Wojtyła, Dzieła literackie 1: 309). Studiował filozofię Huysmansa, która w latach wojny nie miała jeszcze polskiego przekładu, przynajmniej nie cytowana w tekście La Cathédrale: „Nie wiem, Mario, czy Huysmans miał tu rację, gdy wypełnił całe życie swoje takim przeciwstawieniem" (1: 308). Ewentualnie w języku polskim już wówczas mogły się ukazywać artykuły na temat filozofii myśliciela z przełomu XIX i XX wieku: „Przecież właśnie z artykułu wynika, że człowiek jest rzucony na pastwę dwu biegunów - o tutaj, wyraźnie" (1: 309). Kolejnym tropem, który mógłby być pomocny w datowaniu utworu na podstawie zawartych w nim odniesień, które można by potraktować dosłownie, to fakt, że osoby z otoczenia Wojtyły w czasie wojny uczyły się na tajnych kompletach i właśnie do tychże studiów najpewniej odnosi się ten krótki dialog: „Kiedy ty zdajesz ten egzamin? / - Zdaje się, że nie zdążę w tym trymestrze. Odłożę. / - Co się odwlecze, to nie uciecze - mrukną" (1: 311). Do grona tych uczących się osób należała np. Maria Danuta Michałowska $^{10}$, która od listopada studiowała najpierw slawistykę, a następnie filologię polską na Uniwersytecie Jagiellońskim. Z kolei Maria Kydryńska, z którą Karol Wojtyła uczęszczał na lekcje francuskiego do pani Lewaj, nie była studentką romanistyki, bardziej skłaniała się w kierunku nauk przyrodniczych i technicznych. Obie miały 20 lat w 1943 roku: „Bo cóż można myśleć ostatecznie o tej 20-letniej Marii, pracowitej studentce romanistyki” (1: 312-313). Z Marią Kydryńską łączyło go jeszcze jedno wyjątkowe przeżycie - zamykanie powiek zmarłego niespodziewanie ojca: „Tam konał stary człowiek. Poszłam z siostrami, aby go oddać Panu naszemu. Ale przyszłyśmy zaledwie zamknąć mu powieki” (1:315). O ile osierocony Wojtyła ból po stracie rodzica dzielił z rodziną Kydryńskich, to Danuty Michałowskiej nawet nie poinformował o tej tragedii. Ale to, co najcenniejsze w tym tekście medytacyjnym,

\footnotetext{
${ }^{9}$ W czasie okupacji Karol Wojtyła zaczął się uczyć języka francuskiego u pani Jadwigi Lewaj, która wówczas mieszkała u państwa Szkockich, przy ul. Księcia Józefa Poniatowskiego 55a, i to właśnie tam przychodził na lekcje. (Por. Jan Paweł II, Dar i Tajemnica 40). Kiedy w marcu 1944 roku Karol Wojtyła przechodził rekonwalescencję pod troskliwym okiem pani Ireny, to zamieszkał u państwa Szkockich, ale już przy ul. Szwedzkiej 12. Z kolei w liście do państwa Szkockich wysłanym z okazji Świąt Bożego Narodzenia 1946 roku Karol Wojtyła, który w Paryżu zatrzymał się 5 dni, po czym udał się na studia doktoranckie do Rzymu, pisał: „wdzięcznie wspominałem Panią Jadwigę, gdy mogłem się z dość wielką łatwością porozumiewać w Paryżu, a teraz na Angelicum, w Col. des Belges”.

${ }^{10}$ Kiedy 13 listopada 1939 roku szkoły średnie zostały zamknięte, niemal natychmiast podjęła kształcenie w zakresie pierwszej klasy liceum w ramach tajnego nauczania. W czerwcu 1941 roku już zdała maturę, a w listopadzie zaczęła studia na filologii polskiej na Uniwersytecie Jagiellońskim (por. Michałowska, Pamięć nie zawsze święta 356, 357).
} 
to słowa odnoszące się do walki wewnętrznej, z jednej strony silny zew powołania duchownego: „Ale żyło w nim już dwóch ludzi. Jeden się już właściwie oderwał dzięki jakiemuś dziwnemu procesowi, który rozwijał się na pozór tylko w głębi myśli, a drugi trwał siłą uczucia” (1: 312), a z drugiej - właśnie ta siła uczucia: „Mario, Mario - myślał - czy ty jedna naprawdę jesteś tym brzegiem, od którego nie mogę się oderwać i przejść tam” (1: 312). Jednak po latach Ojciec Święty zapytany o „miłość ludzką” odpowiedział krótko: „więcej w tej dziedzinie doznałem Łaski, niż musiałem stoczyć walki. Pewnego dnia stało się dla mnie sprawą wewnętrznie oczywistą, że życie moje nie spełni się w tej miłości, której piękno skądinąd zawsze głęboko odczuwałem" (Frossard 17).

O ile w [Ciagle jestem na tym samym brzegu] jest jeszcze pewne wahanie, niepewność, niepokój, jakaś walka wewnętrzna, o tyle w dramacie [Przyjaciel naszego Boga] Autor poszedł o krok dalej: powołanie zostało jednoznacznie odczytane, decyzja została podjęta. Pomimo to niezwykle trudno określić dokładnie czas powstania pierwszych wersji dramatu o bracie Albercie. Ks. Jan Machniak, publikując je po raz pierwszy w 2013 roku, przyjął, że rękopis pochodzi z 1945 roku. Wydaje się jednak, że należy go datować wcześniej. Przemawiają za tym co najmniej trzy argumenty. Po pierwsze, w tekście jest wiele odniesień biblijnych, nawiązań do mistyki, a to może sugerować, że powstawał on w okresie przyjaźni z Janem Tyranowskim (datującej się od lutego 1940 roku), kiedy to Karol Wojtyła zgłębiał tajniki poezji mistycznej. Po drugie, poruszany w utworze problem wyboru drogi życiowej wiąże się z tym etapem życia Wojtyły, w którym dojrzewała w nim myśl o wstąpieniu do zakonu karmelitów bosych, czyli już po śmierci ojca (18 lutego 1941 roku), po jubileuszowych obchodach czterechsetnej rocznicy urodzin św. Jana od Krzyża (lato-jesień 1942), a być może przed październikiem 1942 roku, kiedy rozpoczął naukę w tajnym Seminarium Duchownym Archidiecezji Krakowskiej. Po trzecie, ograniczona liczba aktorów (sztuka przewidziana dla pięciu osób), umowność postaci scenicznych i sytuacji, ubogi ruch sceniczny, skromność kostiumów i scenografii opisanych w didaskaliach, pozostawienie miejsca dla wyobraźni widza, aby stawał się współtwórcą spektaklu, mogą sugerować, że sztuka ta powstała między latem 1941 a marcem 1943 roku, kiedy to Wojtyła był zaangażowany w działalność Teatru Słowa Mieczysława Kotlarczyka (1: 478). W lipcu 1941 roku przyjechał z Wadowic do Krakowa Mieczysław Kotlarczyk, wraz z żoną zamieszkali u Karola Wojtyły przy ul. Tynieckiej 10. Z kolei w marcu 1943 roku miała miejsce premiera Samuela Zborowskiego - sztuka, którą Karol Wojtyła kończył swoją aktorską karierę i prosił, aby go więcej nie obsadzano do żadnych ról. Jednak i tę datę można przesunąć do połowy 1944 roku, bo jak precyzuje Danuta Michałowska: „16 III Premiera Samuela Zborowskiego Słowackiego, trzymanego w repertuarze TR blisko półtora roku (do czerwca 1944). Samuel Zborowski doczekał się 6 powtórzeń. [...] Rolę tytułową 
«grał» Karol Wojtyła” (, ,...trzeba dać świadectwo” 261-262). Także przy innych okazjach Michałowska mówiąc, że jej kolega „porzucił całkowicie myśl o scenie”, podawała rok 1944 (cyt. za: Świat słowa 111). Kolejną poszlaką istotną w datowaniu tegoż dramatu jest fakt, że Karol Wojtyła zwrócił się do ks. Józefa Matlaka z prośbą o ocenę [Przyjaciela naszego Boga]. Być może miała to być propozycja dla działającego przy parafii św. Stanisława Kostki w Krakowie kółka teatralnego (Perła Ewangeliczna 70). Tym bardziej że każda z dwóch części jest przeznaczona na około 45 minut spektaklu. Ten sam ks. Józef Matlak, jako administrator tejże parafii, wystawił klerykowi Karolowi Wojtyle opinię wymaganą przez kanoniczne przepisy 9 listopada 1944 roku (Kalendarium 77) ${ }^{11}$. Także Stanisław Dziedzic w Romantyku Bożym pisze, że Autor już jako kleryk dał sztukę o Bracie Albercie do przeczytania ks. Matlakowi ok. 1944 roku (Dziedzic 263).

Kiedy Karol Wojtyła znów sięgnął po temat Brata Alberta (redaktorzy wydania z 1979 roku sugerują, że dramat powstał w latach 1945-1950), jego przemyślenia były znacznie dojrzalsze, można powiedzieć, że pojawiła się w nich już w zalążku nauka społeczna Kościoła, którą z czasem z powodzeniem rozwijał jako biskup Krakowa i w końcu jako biskup Rzymu. W dramacie pt. Brat naszego Boga możemy doszukać się tematów poruszanych już w poezjach i w dramacie z okresu wojny, np.:

Nie ma gdzie postawić stopy. Nie ma skrawka ziemi, który by można nazwać swoim. Nie ma kromki chleba, na którą by mogli zapracować. Nie ma dziecka, które by mogli wydać na świat $\mathrm{z}$ tym przeświadczeniem, że nie będzie zawalidrogą. A my w tym wszystkim poruszamy się, zadufani w siłę jakiegoś powszechnego układu, który każe przemilczać rzeczy krzyczące i tłumić usprawiedliwiony wybuch. (Wojtyła, Poezje, dramaty, szkice 328)

Natomiast z drugiej strony możemy domyślać się, że Autor, który pisze: „Znam doki portów, korytarze kopalń i niezmierzone hale fabryczne" (336), naprawdę poznał te miejsca osobiście. A takie doświadczenia zdobył latem i jesienią 1947 roku, kiedy to we Francji spotkał się po raz pierwszy ze Stowarzyszeniem Księży Robotników oraz z ruchem Chrześcijańskiej Młodzieży Robotniczej (,Jeunesse Ouvrire Chrétienne" - JOC), które go szczerze zafascynowały. Pojechał nawet w okolice Charleroi (Belgia), do zagłębia kopalni węgla kamiennego, aby duszpasterzować wśród polskich górników, a że był niezwykle wrażliwy na ich życie i problemy, to od razu nawiązał z nimi świetny kontakt (por. Krystyna Górska, „Tak wiele zawdzięczam Staszkowi”, cyt. za: Tadej 148). Na łamach Tygodnika Powszechnego pisał, że „wytwarza się pewien styl, pewien sposób myślenia i ujmowania zagadnień

${ }^{11} 29$ sierpnia 1977 roku kard. Wojtyła odprawiał pogrzeb ks. J. Matlaka i w przemówieniu nad grobem przypomniał m.in., że zmarły był proboszczem parafii św. Stanisława Kostki na Dębnikach, gdy on odprawiał tam prymicje ... i podkreślił łączącą ich miłość do Brata Alberta (por. Kalendarium 624). 
i posłannictw. Powstające tu kierunki zdają się rozrastać w nową szkołę, w pewną szkołę apostolstwa. Szkoła ta jest - jak bywały wszystkie nowe prądy w Kościele - wysiłkiem, by wrócić do prostoty Ewangelii, do jej źródła i żarliwości” (Wojtyła, „Mission de France” 1). Informacje dotyczące tego okresu zawierają listy Karola Wojtyły kierowane do państwa Szkockich. Rzecz znamienna, że jako adres do korespondencji ks. Wojtyła podawał właśnie „le centre de I.O.C.”. W jednym z listów, z września 1947 roku, z którego bije troska nie tylko o sprawy duchowe, a wiemy, że miedzy innymi wiele czasu spędzał na słuchanie spowiedzi w językach polskim, włoskim i francuskim, pisał:

Jestem w ciągu września duszpasterzem (aumônier) dla robotników polskich w okol. Charleroi (ściśle: Péronnes lez Binche). Znów rozdział ciekawy; pracy jest tu oczywiście więcej, niż człowiek potrafi zrobić, zwłaszcza w ciągu miesiąca, ale to nic. Spotkałem młodego robotnika, który bardzo pragnie odszukać w Polsce swego ojca. Rozstał się z nim w roku 1940 wywieziony do robót w Niemczech; obecnie pracuje tutaj jako górnik. (Listy ks. K. Wojtyły do państwa Szkockich)

Pewne jest, że Brat naszego Boga nie powstał przed listopadem 1946 roku. Można domniemywać, że kiedy Tadeusz Kudliński udał się do Karola Wojtyły i w parlatorium seminaryjnym prosił go o napisanie artykułu bądź felietonu o Bracie Albercie, i kiedy to Wojtyła odmówił mu, uzasadniając, że przyrzekł sobie nie imać się pióra literackiego, póki nie skończy studiów i nie zostanie wyświęcony (T. Kudliński, Głosy teatromana do młodzieńczej biografii Jana Pawła II, cyt. za: Młodzieńcze lata 56), to prawdopodobnie chodzi o okres między październikiem 1945 a listopadem 1946 roku. Przemawia za tym fakt, że po „wyzwoleniu” Krakowa 18 stycznia 1945 roku Seminarium Duchowne Archidiecezji Krakowskiej było zdewastowane i nie nadawało się do mieszkania. Dopiero 20 października 1945 roku seminarium wróciło do swojego domu przy ul. Podzamcze. A Tadeusz Kudliński stanowczo precyzuje, że był właśnie „W siedzibie pod Wawelem” (56). Warto przypomnieć, że klerycy od Wielkanocy 1945 rozpoczęli normalne zajęcia na Wydziale Teologii Uniwersytetu Jagiellońskiego. Pamiętamy też, że Karol Wojtyła 1 listopada 1946 roku przyjął święcenia kapłańskie. Temat Brata Alberta jednak długo nosił w sobie, bo jak był zwykł mówić o swojej twórczości literackiej: „Długo w sobie te rzeczy noszę i - tak bywa - że dopokąd nie są wewnętrznie skończone, nie pozwalają mi się (dosłownie!) napisać" (Wojtyła, Dzieła literackie 1: 362). Dopiero po latach w książce Dar i Tajemnica Jan Paweł II wyjawił, że napisał ów dramat jako młody kapłan w okresie wikariatu u św. Floriana w Krakowie (Jan Paweł II 33), czyli między 1949 a 1951 rokiem.

Utworem zamykającym tom pierwszy Dziet literackich i teatralnych, Juvenilia (1938-1946), w którym Autor osiąga całkowity spokój i szczęście, w którym delektuje się w pełni świadomym wyborem, jest Pieśń o Bogu ukrytym. Jest duże 
prawdopodobieństwo, że ten przepiękny poemat mistyczny powstał przed Bożym Narodzeniem 1943 roku. A jeśli ta hipoteza jest słuszna, to i dwa poprzednie dzieła [Ciagle jestem na tym samym brzegu] i [Przyjaciel naszego Boga], które tematycznie wydają się wcześniejsze, można by datować na okres niewychodzący poza grudzień 1943 roku. Za słusznością tezy, że Pieśń o Bogu ukrytym powstała przed grudniem 1943 roku, przemawia zachowany list, jaki Irena Szkocka napisała, ale nie jest pewne czy wysłała do Karola Wojtyły ${ }^{12}$. Adresatka czytając tekst młodego Wojtyły pisze, że: „Groza wojny i cierpienia została na chwilę za progiem”. Chociaż nie pada tytuł utworu, to jednak jego opis wskazuje jednoznacznie na Pieśń o Bogu ukrytym: „Otulam niemi zranione nogi Boga Ukrytego, obmywam niemi Jego stopy. Z niezmiernym oceanem, prześwietlonym Słońcem Wiekuistym, który zjawił się Twoim zachwyconym oczom”. I kolejne odniesienia: ,próg, którego ptakiem przelecieć nie można”, czy „przed Bogiem Ukrytym - Bogiem Miłującym i spragnionym naszej miłości ... miłości radosnej”, czy w końcu: „Powiedziałeś, że Bóg kocha miejsca bezludne i puste”. List podpisany przez „Babcię Irenę” nie wiemy, czy był datowany w chwili pisania go, czy dopiero po upływie jakiegoś czasu, więc należy wziąć poprawkę na ewentualny margines błędu. Jednak nie ulega wątpliwości, że powstał on w czasie „Grozy wojny i cierpienia”. Sam Autor odkrycie swojego powołania ujął w słowach:

Coraz bardziej jawiło się w mojej świadomości światło: Bóg chce, żebym został kapłanem. Pewnego dnia zobaczyłem to bardzo wyraźnie: był to rodzaj jakiegoś wewnętrznego olśnienia. To olśnienie niosło w sobie radość i pewność innego powołania. I ta świadomość napełniła mnie jakimś wielkim wewnętrznym spokojem. (Jan Paweł II 35)

Utwory nieopatrzone datą wnoszą tę odrobiną tajemniczości, dzięki której stają się jeszcze bardziej zajmujące. Warto podjąć wyzwanie choćby domniemanego datowania niedatowanych utworów, aby do tej wielobarwnej mozaiki, jaką jest twórczość literacka Karola Wojtyły, dopasowywać kolejne elementy. Temat wciąż nie jest zamknięty ani wyczerpany. Pozostaje mieć nadzieję, że kolejne pokolenia badaczy dorobku literackiego Wojtyły, w świetle aktualnych i przyszłych odkryć, dopełnią zapoczątkowanego dzieła.

\footnotetext{
${ }^{12}$ Adnotacja poprzedzająca list: „List Babci Ireny (nie wysłany?) Boże Narodzenie 1943”, który jest zachowany w Archiwum domowym M. Poźniak.
} 


\section{BIBLIOGRAFIA}

Bieniasz, Zbigniew. Kochana stara buda ... Towarzystwo Miłośników Ziemi Wadowickiej, 1986.

Burghardt, Marta. Wadowickie korzenie Karola Wojtyly. Wadowickie Centrum Kultury, 2013.

Dziedzic, Stanisław. „Krakowski świat młodego Karola Wojtyły”. Małopolska Karola Wojtyły - Jana

Pawła II. 5 scen kulturowych. Wystawa zrealizowana w ramach Regionalnego Programu Operacyjnego Województwa Małopolskiego na lata 2014-2020, Instytut Dialogu Międzykulturowego im. Jana Pawła II w Krakowie, 2020, https://idmjp2.pl/index.php/p1/2143-malopolska-karola-wojtyly-jana-pawla-ii-odc-5-dr-stanislaw-dziedzic

Dziedzic, Stanisław. Romantyk Boży. Wydawnictwo M, 2014.

Encyklopedia Krakowa. Wydawnictwo Naukowe PWN, 2000

Frossard, André „Nie lękajcie się!” Rozmowy z Janem Pawłem II. Libreria Editrice Vaticana, 1982.

Gniazdo, z którego wyszedłem, oprac. Karolina Biedrzycka, maszynopis, 1966.

Gruszczyńska, Danuta. W Wadowicach wszystko się zaczęło..., Apostolicum, 2005.

Jan Paweł II. Dar i Tajemnica. W pięćdziesiąta rocznicę moich święceń kaptańskich. Wyd. 2, Wydawnictwo św. Stanisława BM, 2005.

Kalendarium życia Karola Wojtyły, oprac. Adam Boniecki. Wyd. 2, Znak, 2000.

„List Babci Ireny (nie wysłany?) Boże Narodzenie 1943”. Archiwum domowe M. Poźniak.

Listy ks. K. Wojtyły do państwa Szkockich na Boże Narodzenie 1946 roku i z września 1947 roku. Archiwum domowe M. Poźniak.

Michałowska, Danuta. Pamięć nie zawsze święta. Wspomnienia. Wydawnictwo Literackie, 2004.

Młodzieńcze lata Karola Wojtyły. Wspomnienia, red. Juliusz Kudryński, Oficyna Cracovia, 1990.

Pamiatka 400-lecia urodzin św. Jana od Krzyża 1542-1942. Krótki życiorys. List pasterski Generała Zakonu OO. Karmelitów Bosych. Wydana nakładem Ojców Karmelitów Bosych z Rakowickiej 18, 1942.

Perła Ewangeliczna. Życie Stugi Bożego Jana Tyranowskiego, oprac. Michał Szaflarski, Wydawnictwo Współpracowników ks. Bosko, 2017.

Popiel, Jacek. Los artysty w czasach zniewolenia. Teatr Rapsodyczny 1941-1967. Wydawnictwo Uniwersytetu Jagiellońskiego, 2006.

Świat słowa Jana Pawła II. Refleksje - wspomnienia - opinie, oprac. Marta Dalgiewicz, Biblos, 2007.

Tadej, Krzysztof. Dar świętości. Nieznane i zaskakujace wspomnienia o Janie Pawle II. Edycja Świętego Pawła, 2009.

„....trzeba dać świadectwo”. 50-lecie powstania Teatru Rapsodycznego w Krakowie, wybór tekstów, koment. Danuta Michałowska, ArsNova - Zjednoczeni Wydawcy, 1991.

Wadowice w zapiskach klasztornych kronikarzy 1892-1945, oprac. Czesław Gil, Wadowickie Centrum Kultury, 2002.

Wojtyła, Karol. „Mission de France”. Tygodnik Powszechny, nr 9 (207), 1949, ss. 1-2.

Wojtyła, Karol - Jan Paweł II. Dzieła literackie i teatralne, t.1: Juvenilia (1938-1946), red. Jacek Popiel i in., Znak, 2019.

Wojtyła, Karol. Poezje, dramaty, szkice. Jan Paweł II. Tryptyk rzymski. Wstęp Marek Skwarnicki, Znak, 2004. 


\section{DOMNIEMANE DATOWANIE NIEDATOWANYCH UTWORÓW KAROLA WOJTYŁY: DZIEEA LITERACKIE I TEATRALNE, JUVENILIA (1938-1946)}

Streszczenie

Karol Wojtyła pozostawił po sobie wiele niedatowanych utworów. Ustalenie czasu ich powstania wymaga niekiedy detektywistycznego zacięcia. Na podstawie zawartych informacji w poezjach, medytacjach czy w dramatach można z dość dużą dokładnością przybliżyć kontekst ich powstawania. Artykuł jest próbą ustalenia chronologii wczesnych utworów Karola Wojtyły począwszy od adaptacji Obrazu scenicznego pt. „,Chrystus - Król” na podstawie Apokalipsy św. Jana, rymowanych wersów maturzysty, poprzez cykl Sonetów i Symphonie - Scalenia, dalej poezje jesienne, twórczość okresu wojny i okupacji - niekiedy zapomnianej nawet przez samego Autora, kończąc na Pieśni o Bogu ukrytym - najbardziej dojrzałym poemacie sprzed jego święceń kapłańskich. Potwierdzenia zaproponowanych ustaleń często dostarczają wspomnienia osób z otoczenia młodego Wojtyły. Kopalnią wiedzy jest zachowana jego korespondencja do zaprzyjaźnionych rodzin Kotlarczyków czy Szkockich. Dzieła literackie przyszłego papieża, obfitujące w najskrytsze przemyślenia, a często także w obawy i przeczucia, uzupełniają historię poszczególnych etapów jego życia, a przez to pomagają lepiej zrozumieć nie tylko twórczość artystyczną, ale także i nauczanie Jana Pawła II.

Słowa kluczowe: Karol Wojtyła; Jan Paweł II; twórczość literacka; poezje; dramaty; teatr

\section{THE ATTEMPTED DATING OF HITHERTO UNDATED WORKS BY KAROL WOJTYŁA: LITERARY AND THEATRE WORKS, JUVENILIA (1938-1946)}

Sum mary

Karol Wojtyła left behind many undated works. Determining the date of their creation sometimes requires a detective's acumen. Based on the extensive information available in his poetry, meditations or plays, the context of their creation can be worked out quite accurately. This article is an attempt to determine the chronology of the early works of Karol Wojtyła, starting with the adaptation of The Stage Image titled "Christ-King" based on the Apocalypse of Saint John, his rhymed verses as a secondary-school graduate, through the series of Sonnets, and Symphonies - Unifications, then his autumnal poetry, works from the time of the war and occupation - sometimes forgotten by the very author - and ending with Songs about the Hidden God - the most mature poem from the period before his priesthood. Confirmations of the suggested arrangements often come from the recollections of people who were close to the young Wojtyła. His letters to his friends, the Kotlarczyks and the Szkockis, are also an endless source of information. The literary works of the future Pope, full of his deepest thoughts, as well as fears and premonitions, complement the various stages of his life, and thus help us to better understand not only the artistic creativity, but also the teachings, of John Paul II.

Keywords: Karol Wojtyła; John Paul II; literary output; poetry; dramas; theatre 